\title{
PENGEMBANGAN BAHAN AJAR PELUANG DENGAN PENDEKATAN KONTEKSTUAL BERORIENTASI PADA KEMAMPUAN PENALARAN DAN DISPOSISI MATEMATIS BERBASIS ANDROID
}

\author{
Karsoni Berta Dinata ${ }^{1}$, Bobi Arisandi ${ }^{2}$, Darwanto ${ }^{3}$ \\ karsoni.bertadinata@gmail.com \\ 1,3) Universitas Muhammadiyah Kotabumi \\ ${ }^{2)}$ Universitas Pamulang Tanggerang
}

\begin{abstract}
The purpose of this study is to produce a product in the form of opportunity teaching materials with a contextual approach oriented to mathematical reasoning and disposition abilities with an Android-based basis. Teaching material was developed using the development research $(R \& D)$ methodology. Teaching materials are validated, then tested on third semester students of the Mathematics Education Study Program at the University of Muhammadiyah Kotabumi Academic Year 2019/2020. Based on the results of the validation, an assessment is obtained from the side; 1) graphic design obtained a score of 153 in the very good category, 2) presentation of the material obtained a score of 129 was in the very good category, 3) the feasibility of the content obtained a score of 90 was in the very category, 4) Reasoning obtained a score of 37 which is in the good category because are in the interval of $30 \leq S \leq 38$. Furthermore, based on the results of tests on students, an assessment of; 1) aspects of the display is obtained a score of 659 is in the good category, 2) aspects of the presentation of the material obtained by a score of 655 is in good, 3) aspects of the benefits obtained by a score of 1039 are in the good category. Thus it can be concluded that the teaching materials made have met the criteria of validity, practicality, and effectiveness.
\end{abstract}

Keyword: Teaching Material Probability, Mathematical Disposition, Computer Programs

Abstrak: Tujuan dari penelitian ini adalah untuk menghasilkan produk bahan ajar peluang dengan pendekatan kontekstual yang berorientasi pada kemampuan penalaran dan disposisi matematis dengan berbasis android. Bahan ajar dikembangkan dengan metodologi penelitian pengembangan (R\&D). Bahan ajar di validasi, kemudian diujicobakan kepada mahasiswa semester tiga Prodi Pendidikan Matematika Universitas Muhammadiyah Kotabumi Tahun Akademik 2019/2020. Berdasarkan hasil validasi, diperoleh penilaian dari sisi; 1) desain grafis diperoleh skor 153 berada pada kategori sangat baik, 2) penyajian materi diperoleh skor 129 berada pada kategori sangat baik, 3) kelayakan isi diperoleh skor 90 berada pada kategori sangat, 4) Penalaran diperoleh skor 37 yang berada pada kategori baik karena berada dalam interval $30 \leq \mathrm{S} \leq 38$. Selanjutnya berdasarkan hasil ujicoba kepada mahasiswa, diperoleh penilaian dari; 1) aspek tampilan diperoleh skor 659 berada pada kategori baik, 2) aspek penyajian materi diperoleh skor 655 berada pada baik, 3) aspek manfaat diperoleh skor 1039 berada pada kategori baik. Dengan demikian dapat disimpulkan bahwa bahan ajar yang dibuat telah memenuhi kriteria kevalidan, kepraktisan, dan keefektifan.

Kata Kunci: Bahan Ajar Peluang, Disposisi Matematika, Program Komputer

\section{PENDAHULUAN}

Mengacu kepada kurikulum Program studi pendidikan matematika STKIP Muhammadiyah Kotabumi, mata kuliah peluang diajarkan di semester 3. Beberapa mata kuliah seperti mata kuliah statistika matematika menggunakan mata kuliah peluang sebagai mata kuliah prasayarat. Dengan demikian mata kuliah peluang penting untuk dipahami secara menyeluruh 
dan mendalam oleh mahasiswa. Selain itu, Tujuan pembelajaran peluang selaras dengan tujuan program studi pendidikan matematika STKIP Muhammadiyah Kotabumi yaitu agar mahasiswa sebagai calon pendidik memiliki kemampuan dalam hal analisis matematis dengan menggunakan penalaran dan serta memiliki disposisi matematika yang baik.

Berdasarkan pengalaman mengajar mata kuliah peluang, mahasiswa menggunakan sumber belajar hanya dari buku catatan dan internet. Sebagian mahasiswa mencari referensi peluang dari perpustakaan, sayangnya perpustakaan belum memiliki buku khusus yang mengkaji tentang peluang, yang ada hanyalah buku statistika matematika yang membahas peluang sebagai materi prasayarat. Dengan demikian, pengetahuan mahasiswa mengenai peluang kurang menyeluruh dan mendalam. Hal ini berakibat pada rendahnya hasil belajar peluang mahasiswa.

Peluang merupakan materi dasar dalam matematika yang sangat erat kaitanya dalam kehidupan sehari-hari. Mahasiswa dalam mempelajari peluang akan lebih mudah memahami setiap materi peluang jika konsep peluang dikaitkan dalam kehidupan sehari-hari atau kontekstual. Mahasiswa juga akan dengan mudah menggunakan penalaran dalam memecahkan setiap permasalahan peluang yang kontekstual. Konsep peluang dengan pendekatan kontekstual akan semakin menngembangkan kemampuan penalarannya dan membuat mahasiswa menyadari pentingnya matematika.

Saat ini, hampir setiap mahasiswa memiliki smartphone, dan menggunakannya hampir untuk setiap keadaan termasuk untuk belajar. Ada mahasiswa yang berkata lebih baik ketinggalan buku daripada ketinggalan smartphone, ada juga mahasiswa rela pulang jika smartphone-nya tertinggal di rumah. Ini menunjukan bahwa smartphone adalah bagian dari kehidupan mahasiswa. Proses pembelajaran harus dapat mengikuti perkembangan zaman dan tidak boleh terlalu kaku. Pembelajaran saat ini harus mengacu pada tantangan revolusi industry 4.0 .

Berdasarkan paparan tersebut, penulis memandang sangatlah perlu untuk mengembangkan bahan ajar peluang dengan pendekatan kontekstual berorientasi pada kemampuan penalaran matematis dan softskill matematis, yaitu disposisi matematis mahasiswa dengan memanfaatkan aplikasi belajar peluang dalam sistem android pada smartphone mahasiswa.

"Bahan ajar merupakan suatu bentuk bahan yang digunakan dalam membantu pendidik atau guru dalam melaksanakan proses pembelajaran belajar mengajar di kelas. Bahan ajar dapat berbentuk bahan tertulis maupun tidak tertulis" (Amri dan Ahmadi, 2010:159). Bahan ajar tersebut 
berfungsi membantu pendidik dan peserta didik dalam pembelajaran di kelas.

Prastowo (2011:117) menyatakan bahwa "bahan ajar adalah segala bahan yang disusun secara sistematis, yang menampilkan sosok utuh dari kompetensi yang akan dikuasai peserta didik dan digunakan dalam pembelajaran dengan tujuan perencanaan dan penelaahan implementasi pembelajaran. Salah satu bentuk bahan ajar adalah modul".

Berdasarkan beberapa pengertian bahan ajar yang telah dipaparkan di atas, penulis mendefinisikan bahan ajar sebagai seperangkat materi atau substansi pembelajaran (teaching material) yang disusun secara sistematis, menampilkan sosok utuh dari kompetensi yang harus dikuasai peserta didik dalam pembelajaran diarahkan untuk mencapai tujuan pembelajaran.

Pendekatan kontekstual merupkan pendekatan yang menekankan pada kebermaknaan proses pembelajaran. Kebermaknaan pembelajaran akan diperoleh dengan merelevansikan materi pembelajaran dengan kehidupan sehari-hari.

Johnson (2014:65) menyatakan bahwa "Pendekatan kontekstual adalah konsep belajar yang membantu guru mengaitkan antara materi yang diajarkannya dengan situasi dunia nyata siswa dan mendorong siswa membuat hubungan antar pengetahuan yang dimilikinya dengan penerapannya dalam kehidupan siswa sehari-hari, dengan melibatkan tujuh komponen utama dalam pembelajaran efektif yakni: konstruktivis, menanya, menemukan, belajar sosial, pemodelan, refleksi, dan penilaian sebenarnya".

Jadi pendekatan kontektual adalah suatu pendekatan yang berfokus kepada kebermaknaan proses pembelajaran dengan cara mengkaitkan materi pembelajaran dengan kehidupan sehari-hari. Ada tujuh komponen dalam pendekatan kontekstual yaitu konstruktivisme, bertanya, menemukan, masyarakat belajar, pemodelan, refleksi, dan penilaian sebenarnya.

Keraf (1982) menyatakan bahwa "penalaran merupakan proses berpikir dengan cara menghubungkan fakta-fakta yang diketahui untuk mencapai kesimpulan”. Dalam matematika, Shurter dan Pierce (dalam Sumarmo, 1987) mendefinisikan "penalaran matematis adalah proses pengambilan kesimpulan secara logis yang didasarkan kepada fakta dan sumber yang relevan”. Dengan demikian penalaran matematis adalah proses berpikir secara logis untuk mendapatkan sebuah kesimpulan berdasarkan fakta dan sumber yang relevan.

Sumarmo (2012) membagi "penalaran matematis menjadi dua jenis yaitu penalaran induktif dan penalaran deduktif. Penalaran induktif mempunyai beberapa indikator yaitu; a) penalaran transdeduktif yaitu suatu penalaran untuk menarik 
kesimpulan berdasarkan hubungan antara dua kasus atau lebih; b) penalaran analogi yaitu mengambil kesimpulan berdasarkan kesamaan pola suatu fakta); c) penalaran generalisasi yaitu mengambilan kesimpulan umum berdasarkan data yang terbatas); d) memperkirakan jawaban berdasarkan interpolasi dan ektrapolasi; e) menjelaskan suatu model berdasarkan fakta, sifat, hubungan atau pola yang ada; dan f) menerapkan pola hubungan untuk menganalisis keadaan dan menyusun suatu hubungan”.

Disposisi matematis merupakan bagian dari soft skill matematis dan kompetensi sikap sosial matematika. Polking (Dalam Hendriana dkk, 2017:130) menyatakan bahwa dalam "pembelajaran matematika yang berkelanjutan, perilaku positif seperti sikap rasa ingin tahu, perhatan, dan minat dalam mempelajari matematika, serta sikap ulet dan percaya diri mahasiswa akan membentuk suatu kebiasaan berpikir dan berperilaku positif terhadap matematika dinamakan disposisi matematis".

Wardani (2009) menyatakan bahwa "disposisi matematis adalah ketertarikan dan apresiasi terhadap matematika yang ditunjukan melalui kecendrungan berpikir dan bertindak secara positif, termasuk kepercayaan diri, keingin tahuan, ketekunan, antusias dalam belajar, gigih dalam menghadapi permasalahan, fleksibel, berbagi dengan orang lain, dan reflektif dalam kegiatan matematis".
Berdasarkan pendapat para ahli, dapat disimpulkan bahwa disposisi matematis merupakan suatu sikap dan perilaku berpikir positip dalam pembelajaran matematika berupa kepercayaan diri, keingin tahuan, ketekunan, antusias dalam belajar, gigih dalam menghadapi permasalahan, fleksibel, berbagi dengan orang lain, dan reflektif dalam kegiatan matematis.

Putera, dkk (2016) menyatakan bahwa "android adalah sebuah sistem operasi untuk perangkat mobile berbasis linux yang mencakup sistem operasi, middleware, dan aplikasi. Android menyediakan platform terbuka bagi para pengembang untuk menciptakan aplikasi”. Perangkat ini membuat hidup kita begitu manis, maka setiap versi Android dinamai dari makanan penutup (dessert)

Android adalah suatu platform perangkat lunak yang digunakan untuk perangkat mobile yang terdiri atas operation system, Software, middleware, serta pengguna utama aplikasi.

Android dalam penelitian ini akan digunakan sebagai suatu aplikasi yang diinstall dalam smartphone dalam bentuk aplikasi belajar materi peluang yang dapat digunakan setiap saat.

\section{METODE}

Jenis Penelitian ini adalah jenis penelitian Research and Development. Penelitian dan pengembangan dilakukan 
untuk membuat bahan ajar matematika yang kemudian akan digunakan dalam proses pembelajaran. Sugiyono (2015:408) menyatakan "bahan ajar dikembangkan dengan mengikuti langkah-langkah yang ditunjukan pada gambar sebagai berikut”.

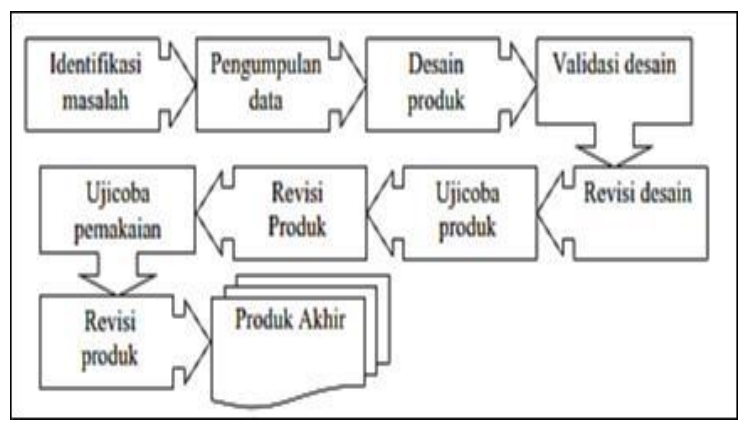

Sumber: (Sugiyono: 2015:409)

Gambar 1.

Langkah-langkah Motede Penelitian dan Pengembangan

Langkah-langkah atau alur dalam penelitian dan pengembangan ini dibatasi yaitu hanya sampai langkah revisi produk uji coba produk (langkah ke-7), mengingat waktu dalam pengembangan bahan ajar yang digunakan. Pada penelitian ini, validasi desain atau produk dilakukan oleh tim ahli, pendidik bidang studi dan beberapa peserta didik saja. Uji pemakaian dibatasi, yaitu pada uji coba produk (uji coba awal) hanya dilakukan pada satu sekolah/kelas saja. Penjelasan mengenai langkah penelitian dan pengembangan pada penelitian ini dijelaskan sebagai berikut.

\section{a) Studi Pendahuluan}

Pada tahap ini, Langkah pertama dalam studi pendahuluan meliputi observasi dan studi literatur. Studi pendahuluan juga diawali dengan kajian problematika pembelajaran materi peluang dikelas. Dinata (2019) menyatakan bahwa 1) Problematika pembelajaran dapat yang berkaitan dengan kesulitan dalam berpikir abstrak dan menalar, 2) Problematika yang berkaitan dengan rendahnya pengetahuan dasar matematika harus dapat diatasi karena sifat matematika yang menganut kebenaran koherensi, dan 3) Problematika yang berkaitan dengan referensi geometri transformasi yang dianggap kurang cocok untuk mahasiswa.

\section{b) Desain Produk}

Pada tahap ini, desain produk atau penyususunan bahan ajar yang terintegrasi dengan pendekatan kontekstual berorientasi pada kemampuan penalaran matematis dan kemampuan disposisi matematis berbasis android. Bahan ajar ini dibuat berdasarkan hasil studi pendahuluan yang telah dilakukan. Materi yang dibahas dalam bahan ajar yaitu Peluang.

\section{c) Validasi Desain (Bahan Ajar) \\ Pemvalidasian bahan ajar matematika} dilakukan oleh ahli, baik ahli materi, dan ahli desain dan media. Pada tahap ini, digunakan lembar penilaian bahan ajar. Lembar tersebut telah divalidasi oleh ahli yang bersangkutan. Para ahli tersebut telah dianggap berkompeten dan dapat dipertanggungjawabkan. Validasi bahan ajar ini dilakukan sebanyak satu kali oleh ahli. 
Setelah dilakukan pemvalidasian oleh ahli, maka telah diketahui kekurangan dalam penyusunan dan pembuatan bahan ajar.

Kemudian bahan ajar diberikan kepada Dosen dan mahasiswa untuk diminta respon atau tanggapan mengenai bahan ajar tersebut. Tahap ini bertujuan untuk mengetahui kelayakan bahan ajar mengenai bagaimana keterbacaan, kemenarikan dan tanggapan dari peserta didik mengenai bahan ajar. Kemudian bahan ajar yang kurang layak atau kurang sesuai dan kurang tepat terhadap peserta didik, maka bahan ajar tersebut dilakukan revisi sampai bahan ajar dianggap sudah tepat, kemudian lanjut pada tahap uji coba produk (bahan ajar).

\section{d) Revisi Desain}

Revisi desain dilakukan sesuai dengan saran dan kritik dari para ahli, baik ahli materi dan ahli media dan desain. Setelah bahan ajar direvisi, kemudian bahan ajar dikonsultasikan terlebih dahulu kepada ahli yang bersangkutan sebelum berlanjut pada tahap berikutnya.

\section{e) Uji Coba Produk}

Pada tahap uji coba produk, produk yang berupa bahan ajar pada penelitian ini diuji cobakan sebanyak satu kali pada satu kelas. Setelah itu untuk mengetahui efektivitas dari bahan ajar yang telah dikembangkan, diberikan angket untuk mengetahui tanggapan dari peserta didik setelah menggunakan bahan ajar yang telah dikembangkan. Darwanto (2017) menyatakan bahwa Hasil ujicoba bahan ajar dapat diketahui efektivitasnya setelah dilakukan respon terhadap responden.

\section{HASIL DAN PEMBAHASAN}

\section{Produk Bahan Ajar peluang}

Produk yang dihasilkan dari penelitian ini berbentuk bahan ajar ajar peluang berbasis Android. Pengembangan Produk diawali dengan mengadakan rapat terkait persiapan penelitian seperti mendata referensi apa saja yang akan dipakai, pengumpulan referensi, dan pembagian kerja penyusunan bahan ajar. Selanjutnya kegiatan penelitian difokuskan untuk menganalisis bahan ajar yang akan dibuat, mengolah referensi yang relevan untuk digunakan, dan mulai membuat bahan ajar.

Bahan ajar terdiri dari materi peluang, soal dan latihan, dan ragam soal. Permasalahan yang di buat harus lebih kontekstual dan menekankan pada strategi pemecahan masalah. Menurut Dinata (2017) dalam memecahkan permaslahan matematika, Problem solver harus cerdas dalam memahami masalah dan memilih strategi yang tepat.

Selanjutnya, bahan ajar yang telah disusun, dilakukan kegiatan edit untuk memperindah tampilan dan memeriksa kembali apakah masih ada tulisan yang mungkin salah ketik atau istilah yang salah, 
mendiskusikan materi yang telah dibuat, membahas soal-soal, dan memeriksa apakah soal sudah sesuai dengan materi ajar. Selanjutnya dikembangkan bahan ajar peluang dalam bentuk program komputer.

Berikut tampilan utama bahan ajar peluang berbasis peluang.

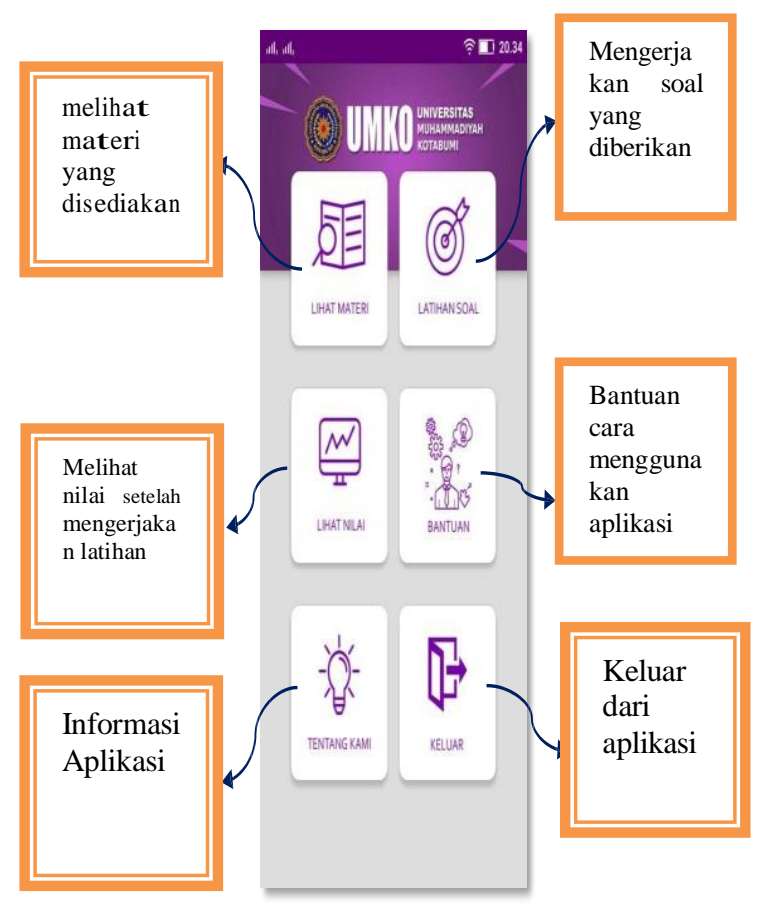

Gambar 2.

Halaman Utama Aplikasi

\section{Hasil Validasi Bahan Ajar}

Validasi bahan ajar peluang berbasis android dilaksanakan kepada para ahli yang terdiri dari tiga orang yang dipandang ahli dalam pendidikan matematika. Validasi dilakukan dengan melihat dari aspek desain dan bahasa dan aspek materi. Aspek Desain dan bahasa terdiri 1) kelayakan kegrafikan, dan penyajian materi. Aspek materi terdiri dari 1) aspek kelayakan isi, 2) Penyajian Materi, dan 3) Penalaran dan Penilaian
Validasi dilaksanakan kepada para ahli untuk menilai dari aspek;

1) kelayakan kegrafikan

Berdasarkan hasil analisis kelayakan kegrafikan diperoleh daftar interval nlai masing-masing kategori yang disajikan dalam tabel berikut.

Tabel 1.

Kategori kelayakan kegrafikan

\begin{tabular}{|c|c|c|}
\hline Skor & Katagori & Interval Nilai \\
\hline 4 & Sangat Baik & $144 \leq \mathrm{S} \leq 180$ \\
\hline 3 & Baik & $111 \leq \mathrm{S}<144$ \\
\hline 2 & Kurang & $78 \leq \mathrm{S}<111$ \\
\hline 1 & Sangat Kurang & $45 \leq \mathrm{S}<78$ \\
\hline
\end{tabular}

Berdasarkan hasil perhitungan skor kelayakan kegrafikan yaitu 153. Dengan demikian penilaian dari aspek kelayakan kegrafikan sangat baik.

2) Penyajian Materi

Berdasarkan hasil analisis penyajian materi diperoleh daftar interval nlai masingmasing kategori yang disajikan dalam tabel berikut.

Tabel 2

Kategori Penyajian Materi

\begin{tabular}{|c|c|c|}
\hline Skor & Katagori & Interval Nilai \\
\hline 4 & Sangat Baik & $126 \leq \mathrm{S} \leq 156$ \\
\hline 3 & Baik & $97 \leq \mathrm{S} \leq 126$ \\
\hline 2 & Kurang & $68 \leq \mathrm{S} \leq 97$ \\
\hline 1 & Sangat Kurang & $39 \leq \mathrm{S}<68$ \\
\hline
\end{tabular}


Berdasarkan hasil perhitungan skor aspek penyajian materi yaitu 129. Dengan demikian penilaian dari aspek penyajian materi sangat baik.

\section{3) Kelayakan Isi}

Berdasarkan hasil analisis kelayakan isi diperoleh daftar interval nlai masingmasing kategori yang disajikan dalam tabel berikut.

Tabel 3.

Kategori Kelayakan Isi

\begin{tabular}{|c|c|c|}
\hline Skor & Katagori & Interval Nilai \\
\hline 4 & Sangat Baik & $87 \leq \mathrm{S} \leq 108$ \\
\hline 3 & Baik & $67 \leq \mathrm{S} \leq 86$ \\
\hline 2 & Kurang & $47 \leq \mathrm{S} \leq 66$ \\
\hline 1 & Sangat Kurang & $27 \leq \mathrm{S} \leq 46$ \\
\hline
\end{tabular}

Berdasarkan hasil perhitungan skor aspek kelayakan isi yaitu 90. Dengan demikian penilaian dari aspek kelayakan isi sangat baik.

\section{4) Penyajian Materi}

Berdasarkan hasil analisis Penyajian Materi diperoleh daftar interval nlai masing-masing kategori yang disajikan dalam tabel berikut.

Tabel 4.

Kategori Penyajian Materi

\begin{tabular}{|c|c|c|}
\hline Skor & Katagori & Interval Nilai \\
\hline 4 & Sangat Baik & $69 \leq \mathrm{S} \leq 84$ \\
\hline 3 & Baik & $53 \leq \mathrm{S} \leq 68$ \\
\hline 2 & Kurang & $37 \leq \mathrm{S} \leq 52$ \\
\hline 1 & Sangat Kurang & $21 \leq \mathrm{S} \leq 36$ \\
\hline
\end{tabular}

Berdasarkan hasil perhitungan skor aspek Penyajian Materi yaitu 68 . Dengan demikian penilaian dari aspek Penyajian Materi baik.

5) Penalaran dan Penilaan.

Berdasarkan hasil analisis Penalaran dan Penilaan diperoleh daftar interval nlai masing-masing kategori yang disajikan dalam tabel berikut.

Tabel 5.

Kategori Penalaran dan Penilaian

\begin{tabular}{|c|c|c|}
\hline Skor & Katagori & Interval Nilai \\
\hline 4 & Sangat Baik & $39 \leq \mathrm{S} \leq 48$ \\
\hline 3 & Baik & $30 \leq \mathrm{S} \leq 38$ \\
\hline 2 & Kurang & $21 \leq \mathrm{S} \leq 29$ \\
\hline 1 & Sangat Kurang & $12 \leq \mathrm{S} \leq 20$ \\
\hline
\end{tabular}

Berdasarkan hasil perhitungan skor aspek Penalaran dan Penilaan yaitu 37. Dengan demikian penilaian dari aspek Penalaran dan Penilaan baik.

\section{Hasil Ujicoba}

Ujicoba Produk penelitian dilaksanakan setelah Produk di validasi dan dilaksanakan revisi berdasarkan hasil validasi. Ujicoba Produk dilaksanakan selama proses pembelajaran. Pembelajaran menggunakan pembelajaran kolaboratif. Dinata (2018) menyatakan salah satu upaya untuk meningkatkan kualitas pembelajaran secara kontinu adalah dengan pembelajaran kolaboratif dengan siklus plan, do, see 
Berikut penjelasan hasil analisis data ujicoba.

\section{1) Aspek Tampilan}

Berdasarkan hasil analisis ujicoba aspek tampilan diperoleh daftar interval nlai masing-masing kategori yang disajikan dalam tabel berikut.

Tabel 6

Kategori Aspek Tampilan

\begin{tabular}{|c|c|c|}
\hline Skor & Katagori & Interval Nilai \\
\hline 4 & Sangat Baik & $706 \leq \mathrm{S} \leq 868$ \\
\hline 3 & Baik & $543 \leq \mathrm{S} \leq 705$ \\
\hline 2 & Kurang & $380 \leq \mathrm{S} \leq 542$ \\
\hline 1 & Sangat Kurang & $217 \leq \mathrm{S} \leq 379$ \\
\hline
\end{tabular}

Berdasarkan hasil perhitungan skor aspek tampilan yaitu 659. Dengan demikian penilaian dari aspek tampilan baik.

\section{2) Aspek Penyajian Materi}

Berdasarkan hasil analisis ujicoba aspek penyajian materi diperoleh daftar interval nlai masing-masing kategori yang disajikan dalam tabel berikut.

\section{Tabel 7.}

Kategori Penyajian Materi

\begin{tabular}{|c|c|c|}
\hline Skor & Katagori & Interval Nilai \\
\hline 4 & Sangat Baik & $706 \leq \mathrm{S} \leq 868$ \\
\hline 3 & Baik & $543 \leq \mathrm{S} \leq 705$ \\
\hline 2 & Kurang & $380 \leq \mathrm{S} \leq 542$ \\
\hline 1 & Sangat Kurang & $217 \leq \mathrm{S} \leq 379$ \\
\hline
\end{tabular}

Berdasarkan hasil perhitungan skor aspek penyajian materi yaitu 655. Dengan demikian penilaian dari aspek penyajian materi baik.

\section{3) Aspek manfaat}

Berdasarkan hasil analisis ujicoba aspek manfaat materi diperoleh daftar interval nlai masing-masing kategori yang disajikan dalam tabel berikut.

Tabel 8.

Kategori Aspek Manfaat

\begin{tabular}{|c|c|c|}
\hline Skor & Katagori & Interval Nilai \\
\hline 4 & Sangat Baik & $1109 \leq \mathrm{S} \leq 1364$ \\
\hline 3 & Baik & $853 \leq \mathrm{S} \leq 1108$ \\
\hline 2 & Kurang & $597 \leq \mathrm{S} \leq 852$ \\
\hline 1 & Sangat Kurang & $341 \leq \mathrm{S} \leq 596$ \\
\hline
\end{tabular}

Berdasarkan hasil perhitungan skor aspek manfaat yaitu 1039. Dengan demikian penilaian dari aspek manfaat baik.

\section{SIMPULAN}

Berdasarkan data hasil validasi dapat Bahan ajar peluang berbasis android ini telah memenuhi syarat dan standar kelayakan berdasarkan penilaian ahli materi, ahli desain, dan media.

Berdasarkan data hasil ujicoba dapat disimpulkan bahwa produk ajar berdasarkan hasil respon dari mahasiswa, produk bahan ajar peluang berbasis android dinyatakan baik dan telah memenuhi aspek tampilan, penyajian materi dan aspek manfaat. 


\section{DAFTAR RUJUKAN}

Amri, S. dan Ahmadi, I. K. (2010). Kontruksi Pengembangan Pembelajaran. Prestasi Pustaka. Jakarta. $242 \mathrm{hlm}$.

Darwanto, D., Caswita, C., \& Suharsono, S. (2017). Pengembangan Bahan Ajar Dengan Model Pbl Untuk Mengembangkan Kemampuan Berpikir Kreatif Siswa. Jurnal Pendidikan Matematika Unila, 5(1).

Dinata, K. B. (2017). Strategi Pemecahan Masalah dalam Matematika. Eksponen, 7(2), 54-60.

Dinata, K. B. (2018). Inovasi Pembelajaran Aljabar Ring Melalui Lesson Study. Eksponen, 8(1), 53-59.

Dinata, K. B. (2019). Problematika Membangun Pemahaman Konsep Geometri Transformasi Mahasiswa Pendidikan Matematika di Universitas Muhammadiyah Kotabumi Tahun Akademik 2019/2020. Eksponen, 9(2), 01-09.

Hendriana, dkk. (2017). Hard Skills dan Soft Skills Matematik Siswa. Bandung: Refika Aditama.

Johnson. E. B. (2014). CTL: Contextual Teaching \& Learning. Bandung: Kaifa

Keraf, G. (1982). Argumen dan Narasi Komposisi Lanjutan III. Jakarta: Gramedia.

Prastowo, A. (2011). Panduan Kreatif Membuat Bahan Ajar Inovatif. Diva Press. Yogyakarta.

Sumarmo, Utari. 1987. Kemampuan Pemahaman dan Penalaran Matematika Siswa SMA Dikaitkan dengan Kemampuan Penalaran logis Siswa dan Beberapa Unsur Proses Belajar Mengejar. Disertasi pada Pascasarjana IKIP Bandung. 